\title{
Formation of Coarse Silicon Near the Surface of Al-7Si-Mg Semi-solid Castings
}

\author{
JORGE SANTOS, ANDERS E.W. JARFORS, and ARNE K. DAHLE
}

\begin{abstract}
Primary type polyhedral silicon crystals were observed in the vicinity of oxides located at or near the surface of strontium modified semi-solid $\mathrm{Al}-7 \mathrm{Si}-\mathrm{Mg}$ castings. The coarse silicon polyhedrons were observed mainly on the outer side of oxides surrounding the macrosegregation regions. The silicon crystals most likely nucleated on AlP-particles located near the oxides. These AlP particles may nucleate on the wetted surface of oxides, or form at different locations in the interdendritic regions.
\end{abstract}

https://doi.org/10.1007/s11661-021-06462-8

(C) The Author(s) 2021

PHOSPHORUS is commonly added to hypereutectic Al-Si alloys to form Aluminium Phosphide (AlP) particles which act as potent nucleants for primary silicon crystals. ${ }^{[1,2]}$ Ho and Cantor ${ }^{[3]}$ and Nogita et al. ${ }^{[4]}$ showed experimentally that eutectic silicon nucleates on AlP particles. Phosphorus is a common impurity in commercial purity aluminium at levels ranging from 5 to $15 \mathrm{ppm}^{[5,6]}$ The addition of alloying elements, also containing phosphorous as an impurity, to produce aluminium foundry alloys may increase phosphorus levels up to $20 \mathrm{ppm} .{ }^{[6]}$ However, in commercial purity hypoeutectic Al-Si alloys, phosphorus is commonly reported as $<10 \mathrm{ppm}^{[5]}$ The phosphorus and silicon contents of an aluminium alloy and cooling rate determine whether or not AlP form at temperatures above the Al-Si eutectic. ${ }^{[3]}$ Ho and Cantor, ${ }^{[3]}$ using the droplet technique, found that AIP can precipitate and act as heterogeneous nucleants for eutectic silicon in an $\mathrm{Al}-3 \mathrm{Si}$ alloy with a phosphorus content in the range of 0.25 to $2 \mathrm{ppm}$ and a cooling a rate of $10{ }^{\circ} \mathrm{C} / \mathrm{min} \cdot{ }^{[3]}$ Liang and Fetzer ${ }^{[7]}$ showed by thermodynamic calculations, supported by experimental data, that AlP precipitate at temperatures above the $\mathrm{Al}-\mathrm{Si}$ eutectic temperature for Al-7Si alloys with phosphorus contents above $3.7 \mathrm{ppm}$.

Strontium modification is used to improve the mechanical properties of $\mathrm{Al}-\mathrm{Si}$ foundry alloys by altering the morphology of eutectic silicon. ${ }^{[8,9]}$ The strontium level of an Al-Si alloy determines if the $\mathrm{Al}_{2} \mathrm{Si}_{2} \mathrm{Sr}$ intermetallic will form during solidification and at which temperature ${ }^{[10]}$ For a certain level of strontium addition, the $\mathrm{Al}_{2} \mathrm{Si}_{2} \mathrm{Sr}$ can form on AlP before the $\mathrm{Al}-\mathrm{Si}$

JORGE SANTOS, ANDERS E. W. JARFORS and ARNE K. DAHLE are with the Department of Materials and Manufacturing, School of Engineering, Jönköping University, P.O Box 1026, 55111, Jönköping, Sweden. Contact e-mail: jorge.santos@ju.se

Manuscript submitted June 8, 2021; accepted September 9, 2021.

Article published online September 30, 2021 eutectic reaction and thereby reduce the number of available AlP-nuclei for the nucleation of eutectic silicon ${ }^{[10,11]}$ Using thermodynamic calculations, Eiken et al. ${ }^{[10]}$ verified that for an Al-7Si alloy with $5 \mathrm{ppm}$ phosphorus, the addition of $100 \mathrm{ppm}$ of strontium is necessary to modify the eutectic silicon. At lower levels of strontium addition, $\mathrm{Al}_{2} \mathrm{Si}_{2} \mathrm{Sr}$ does not form before the Al-Si eutectic reaction and the AlP particles are not deactivated. ${ }^{[10]}$ The thermodynamic calculations in Reference [10] are in good agreement with the experimental results of Dahle et al. ${ }^{[12]}$

Crack-like defects have been observed within eutectic silicon and are associated with the presence of oxides that may act as nucleation sites for eutectic silicon. ${ }^{[13]}$ Additionally, it has been assumed that the AlP particles nucleate on the outer wetted surfaces of double oxide films, and subsequently, the silicon crystals nucleate on AlP. ${ }^{114,15]}$ Strontium-rich $\mathrm{Al}_{2} \mathrm{Si}_{2} \mathrm{Sr}$ with a centrally located AlP-particle were observed well-aligned along an oxide surface. ${ }^{[15]}$ Therefore, Campbell et al.$^{[15]}$ suggested that AlP formed on the wetted side of double oxide films, nucleate $\mathrm{Al}_{2} \mathrm{Si}_{2} \mathrm{Sr}$.

This study aims to show additional indications of the role of oxides and AIP for the nucleation of eutectic silicon in hypoeutectic Al-Si alloys.

A series of Semi-Solid Metal (SSM) Al-7Si-Mg castings, with 0.3 and $0.6 \mathrm{wt}$ pct magnesium, were produced by the Rheometal ${ }^{\mathrm{TM}}{ }^{[16]}$ process. The alloys used in this study to obtain the SSM castings were melted and held at $700{ }^{\circ} \mathrm{C}$ in an electrical resistance furnace. The chemical composition of the alloys, measured with a Spectro Max CCD LMXM3 optical emission spectrometer, is shown in Table I.

A slurry consisting of near-globular primary $\alpha$-Al crystals dispersed in the liquid was prepared and poured into the shot-sleeve of a 50-tonne vertical high-pressure die casting machine. For the slurry preparation, cylinders of $\varnothing 40 \mathrm{~mm}$ from each alloy were cast in a copper 
Table I. Average Chemical Composition of the Al-7Si-Mg Alloys Used in This Study in Wt Pct

\begin{tabular}{lccccccc}
\hline Alloy & $\mathrm{Si}$ & $\mathrm{Mg}$ & $\mathrm{Fe}$ & $\mathrm{Ti}$ & $\mathrm{Sr}$ & $\mathrm{P}$ & $\mathrm{Al}$ \\
\hline Al-7Si-0.3Mg & 7.02 & 0.32 & 0.14 & 0.09 & 0.020 & $<0.001$ & Bal. \\
Al-7Si-0.6Mg & 7.11 & 0.60 & 0.12 & 0.12 & 0.024 & $<0.001$ & Bal. \\
\hline
\end{tabular}

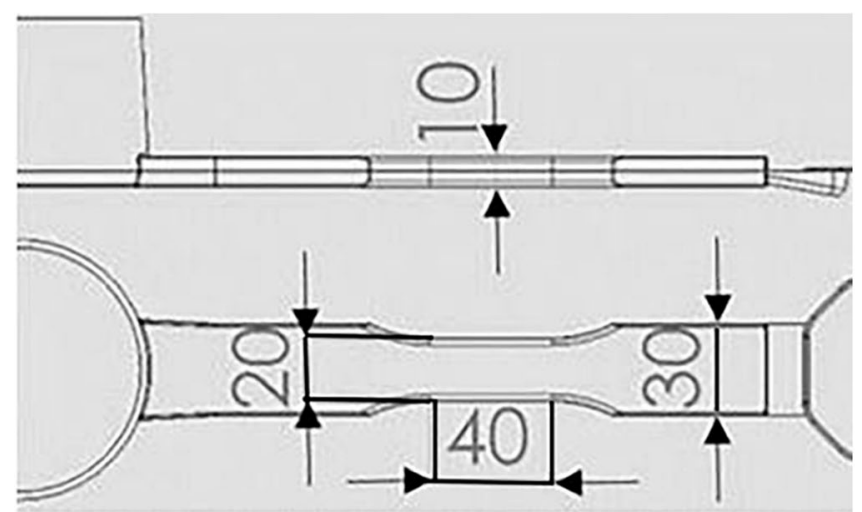

(a)

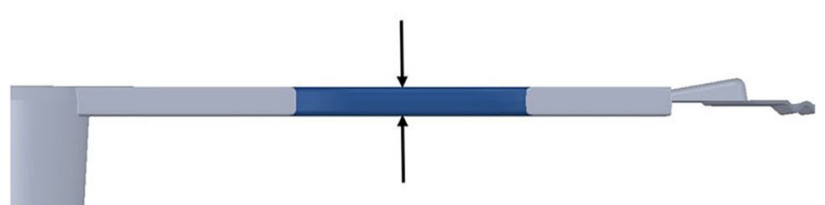

(b)

Fig. 1-(a) SSM casting shape and dimensions in $\mathrm{mm}$ and $(b)$ illustration of the region from which the samples were cut and surfaces polished (indicated by the arrows).

mould with internal water-cooled channels. The cylinders, so-called Enthalpy Exchange Material (EEM), ${ }^{[17]}$ were cast with a $\varnothing 12 \mathrm{~mm}$ steel rod in the centre. After casting, the height of the EEM was adjusted to make the EEM about $7 \mathrm{wt}$ pct of the total shot weight. The EEMs, pre-heated to $200{ }^{\circ} \mathrm{C}$, were connected through the steel rod to a stirring device and, rotating at 850 $\mathrm{rpm}$, were immersed into about $1.3 \mathrm{~kg}$ of the same alloy at $650{ }^{\circ} \mathrm{C}$. After preparation $(\sim 18 \mathrm{~s}$ after the EEM immersion), the slurry was poured into the shot-sleeve and injected into the die-cavity to produce the castings, as shown in Figure 1(a). A plunger speed of $0.3 \mathrm{~m} / \mathrm{s}$ and an intensification pressure of 160 bar were used for all castings. A duration of $10 \mathrm{~s}$ was set for the intensification pressure stage. A PolyTemp HTF 300 heater was used to control the die temperature by keeping the oil circulation in the internal channels of the die at a constant temperature of $175^{\circ} \mathrm{C}$. A set of high pressure die castings were produced before the experiments started to maintain reproducible thermal conditions in the shot sleeve and die-cavity.

Samples were cut from the reduced section of the castings, and the casting surfaces were polished for metallographic investigation, as shown in Figure 1(b). The polishing operation removed less than $190 \mu \mathrm{m}$ depth of the surface. A JEOL JSM-7001F Scanning Electron Microscopy (SEM) equipped with Energy-Dispersive X-ray Spectroscopy (EDS) was used to identify the phases in the different samples. A fixed acceleration voltage of $15 \mathrm{kV}$ was used for all EDS analyses. Wavelength-Dispersive Spectroscopy (WDS) was conducted at a fixed acceleration voltage of $10 \mathrm{kV}$ and pure aluminium, silicon, and magnesium samples were used as standards.
Figure 2(a) shows the microstructure of the SSM Al-7Si-0.3Mg casting surface consisting of mostly small $\alpha$-Al dendrites and modified eutectic. Additionally, coarse polyhedral silicon crystals are observed at the outer surface and vicinity of oxides, as shown in Figure 2(a). A region of positive macrosegregation is also observed, i.e., rich in eutectic, most likely formed by exudation, ${ }^{[18]}$ as shown in Figure 2(a). The microstructure of the macrosegregation regions consisted of mostly modified eutectic and was, therefore, the last region to solidify in the surface layer. The concentration of silicon, magnesium and iron in these macrosegregation regions measured by EDS point analysis were $15.34 \pm 1.36,2.47 \pm 0.19$ and $0.54 \pm 0.10$ wt pct, respectively. Coarse polyhedral silicon crystals were also found near the surface of the $\mathrm{Al}-7 \mathrm{Si}-0.3 \mathrm{Mg}$ ingot used as raw material to produce the SSM Al-7Si-0.3Mg castings, as shown in Figure 2(b). These polyhedral silicon crystals near the A17Si-0.3Mg ingot surface were also observed near oxides.

Figure 3 shows the microstructure and the corresponding EDS elemental maps of a region near the SSM Al-7Si-0.6Mg casting surface. Similar to the SSM Al-7Si-0.3Mg casting surface, coarse silicon was observed at the outer surface and the vicinity of oxides located near the SSM Al-7Si-0.6Mg castings surface, as shown in Figures 3(a) and (b). In both castings, SSM $\mathrm{Al}-7 \mathrm{Si}-0.3 \mathrm{Mg}$ and $\mathrm{Al}-7 \mathrm{Si}-0.6 \mathrm{Mg}$, most of the coarse silicon crystals were observed in the vicinity of the oxides. Figure 3(c) shows oxygen-rich regions at the discontinuity location (Figure 3(a)), which confirms the presence of oxides. The formation of coarse silicon has been reported in strontium modified sand and permanent mould castings of hypoeutectic Al-Si alloys. ${ }^{[19]}$ The 


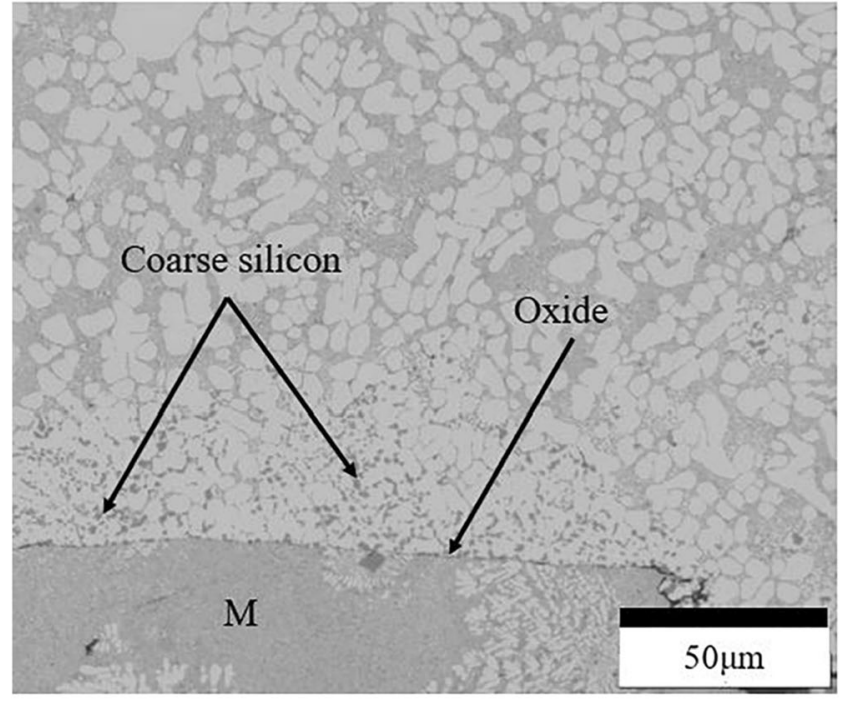

(a)

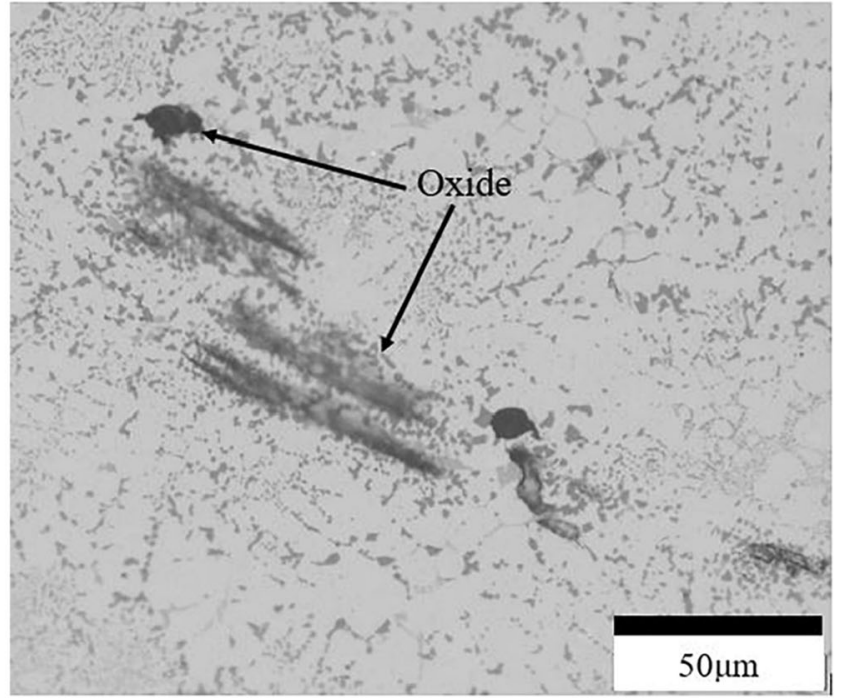

(b)

Fig. 2-Optical micrographs of the surface of the (a) SSM Al-7Si-0.3 Mg castings and (b) Al-7Si-0.3Mg ingot before melting. M-Positive macrosegregation region of silicon, magnesium and iron.

presence of potent AlP nucleant particles in the liquid at temperatures higher than $\mathrm{Al}-\mathrm{Si}$ eutectic reaction is commonly associated with the formation of course eutectic silicon in unmodified alloys. ${ }^{[4,12]}$

An elevated phosphorus concentration is observed at the location of the oxides, as seen in Figure 3(d). $\mathrm{AlPO}_{4}$ is a typical reaction product found when phosphorus-based refractory binders are used at some stage during aluminium production. ${ }^{[20]}$ Nogita et al. ${ }^{[4]}$ showed that AlP has a common orientation relationship with the adjacent eutectic silicon, confirming that AlP nucleates eutectic silicon. Ludwig et al. ${ }^{[20]}$ showed evidence of nucleation of primary type silicon crystals on AlP with silicon platelets growing radially from them. Therefore, it can be assumed that the regions with high phosphorus concentration observed in Figure 3(d) result from the presence of AlP.

The AlP particles need to pre-exist or form at temperatures above the $\mathrm{Al}-\mathrm{Si}$ eutectic temperature in order to nucleate eutectic silicon. The phosphorus and silicon contents of the alloy ${ }^{[7]}$ and cooling rate ${ }^{[3]}$ dictate the temperature at which AlP forms. The quantification of the phosphorus concentration of aluminium alloys is difficult ${ }^{[21,22]}$ and optical emission spectrometry is not accurate due to interference from the iron and manganese peaks with the phosphorus. ${ }^{[22]}$ Therefore, the phosphorus content of $<10$ ppm measured in this work is uncertain (Table I). For an Al-7Si alloy, the phosphorus concentration necessary for the formation of AlP at temperatures above the $\mathrm{Al}-\mathrm{Si}$ eutectic reaction temperature is lower than the typical commercial purity range $<10$ ppm. ${ }^{[10]}$ Therefore, it is expected that AlP pre-exists or form in commercial purity Al-Si alloys and nucleate eutectic silicon. ${ }^{[7]}$

Strontium addition to $\mathrm{Al}-\mathrm{Si}$ foundry alloys can reduce the nucleation frequency of $\mathrm{Al}-\mathrm{Si}$ eutectic grains by the formation of $\mathrm{Al}_{2} \mathrm{Si}_{2} \mathrm{Sr}$ on $\mathrm{AlP}$. ${ }^{[23]}$ The strontium and silicon contents dictate the temperature at which the
$\mathrm{Al}_{2} \mathrm{Si}_{2} \mathrm{Sr}$ is stable for an $\mathrm{Al}-\mathrm{Si}$ alloy. ${ }^{[10]}$ Consequently, there is a critical strontium level at which $\mathrm{Al}_{2} \mathrm{Si}_{2} \mathrm{Sr}$ precipitates at temperatures above the $\mathrm{Al}-\mathrm{Si}$ eutectic reaction and thereby deactivate $A 1 P .{ }^{[10]}$ The deactivation of the AlP particles results in a decrease of nucleation temperature and reduction of the nucleation frequency of the $\mathrm{Al}-\mathrm{Si}$ eutectic. ${ }^{[10]}$ However, if $\mathrm{Al}_{2} \mathrm{Si}_{2} \mathrm{Sr}$ does not deactivate AlP, a larger number of eutectic grains form at low undercooling and grow at lower rates, resulting in the formation of coarser silicon. ${ }^{[10,23]}$

At high cooling rates, the nucleation of AlP can be suppressed, ${ }^{[24]}$ suggesting that any significant AlP precipitation during solidification in the die-cavity in this study is unlikely. Therefore, the AlP particles are most likely formed either during slurry preparation or/and holding in the shot sleeve. Table II shows the silicon concentration measured in the interior of the slurry primary $\alpha$-Al globules $(>25 \mu \mathrm{m})$ by WDS and the corresponding final slurry temperature. The silicon concentration in the interior of the $\alpha$-Al globules was used to obtain the corresponding slurry temperature in Thermocalc ${ }^{\mathrm{TM}}$, similar to Reference [25].

Figure 4 shows the vertical section of the Al-7Si-P phase diagram adapted from Liang and Schmid-Fetzer. ${ }^{[7]}$ At the slurry temperatures (Table II), the formation of AlP occurs at phosphorus levels above 9 ppm, as shown in Figure 4. Assuming a phosphorus content commonly reported for commercial purity aluminium alloys, $<10 \mathrm{ppm}$, it is unlikely that the formation of AlP occurred during slurry preparation. However, AlP may form during holding in the shot sleeve due to the decrease of temperature and relatively low cooling rate. ${ }^{[24]}$

AlP can remain stable for several hours at $800{ }^{\circ} \mathrm{C}$ in Al-Si melts. ${ }^{[26]}$ Therefore, AlP formed during ingot production can remain undissolved after melting the $\mathrm{Al}-7 \mathrm{Si}-\mathrm{Mg}$ ingots at $700{ }^{\circ} \mathrm{C}$ for producing the SSM castings. Figure 2(b) shows primary type silicon crystals 


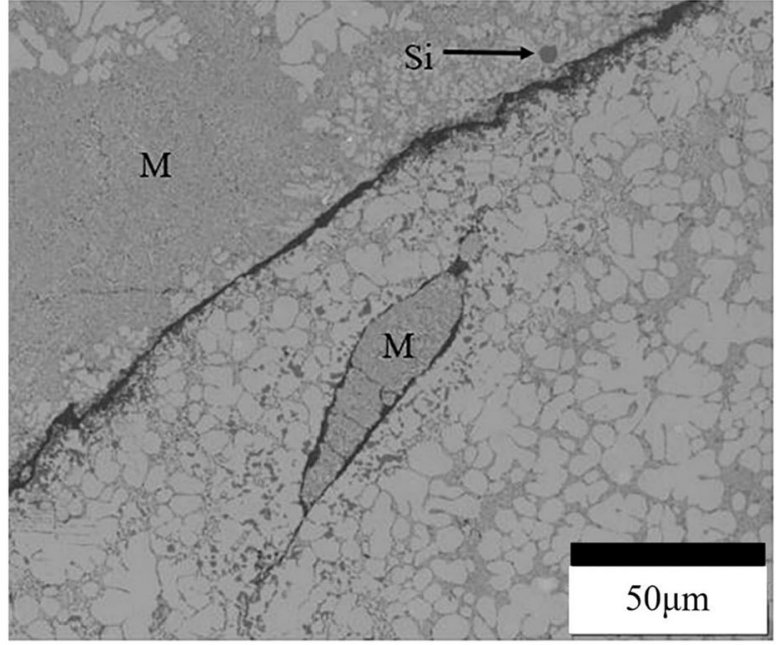

(a)

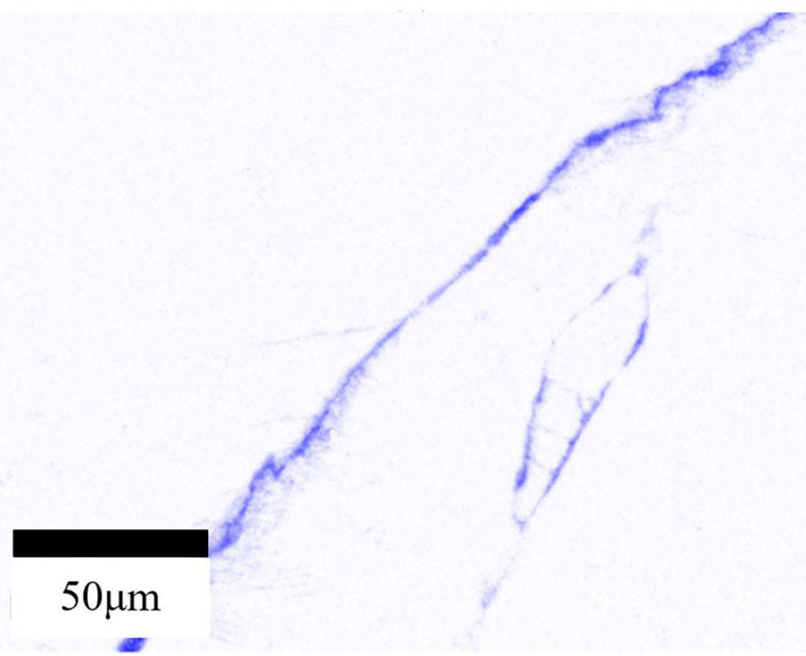

(c)

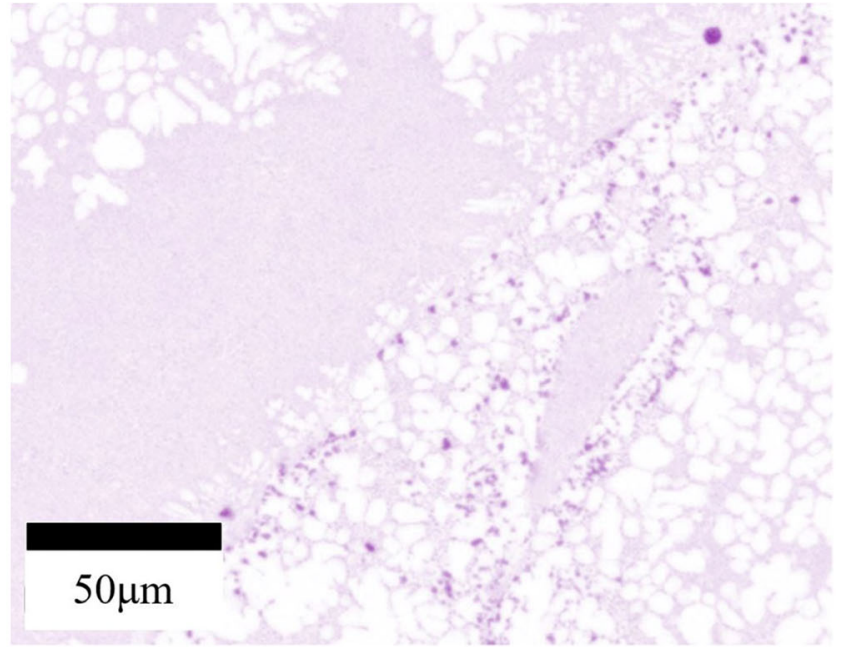

(b)

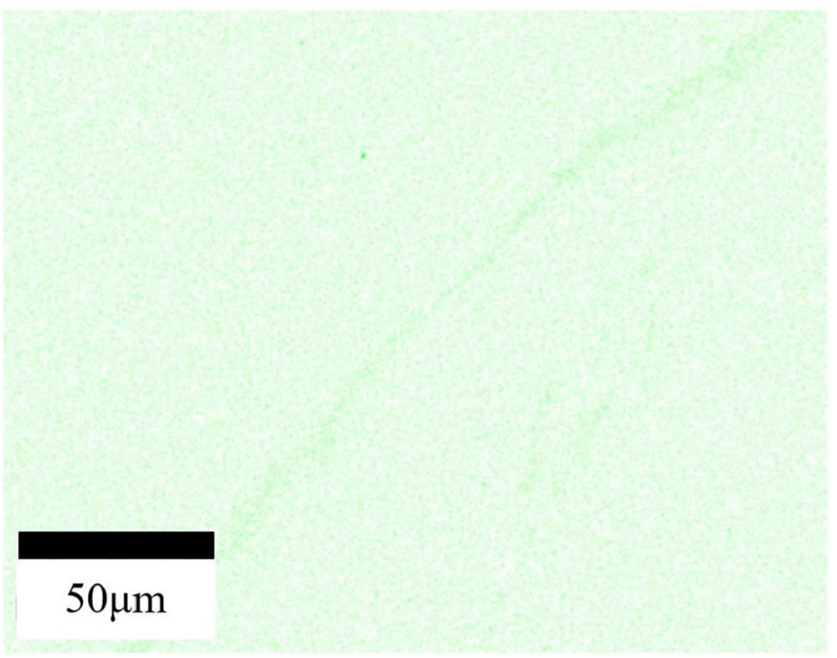

(d)

Fig. 3-(a) Optical micrograph of the SSM Al-7Si-0.6Mg casting in the T5 condition. EDS elemental maps for $(b)$ silicon, $(c)$ oxygen, and $(d)$ phosphorus obtained from the region in (a). Si-primary silicon. $\mathrm{M}$ - positive macrosegregation region. (Colour figure online).

formed in the surface layer of the ingots used to produce the SSM castings. These primary type silicon crystals near the ingot surface most likely nucleated on AlP that can remain active after melting of the ingots at $700{ }^{\circ} \mathrm{C}$.

Campbell ${ }^{[14,15]}$ suggested that AlP nucleates on the outer wetted surface of oxide double films and that these AlP particles can nucleate eutectic silicon. Figures 2 and 3 show that the silicon polyhedrons formed on the outer side wetted surface of the oxides surrounding the macrosegregation regions. Therefore, it is possible that the AlP particles formed on the outer wetted surface of oxides, and susbsequently, nucleated the primary type silicon polyhedral crystals. ${ }^{[14]}$ A high phosphorous concentration in the liquid adjacent to the wetted oxide surface would be required for the formation of numerous AlP particles to nucleate the primary type silicon observed in Figures 2(a) and 3(a). Zhu et al. ${ }^{[2]}$ showed that AlP tended to nucleate on or attach to the $\gamma-\mathrm{Al}_{2} \mathrm{O}_{3}$ oxide formed on the surface of an $\mathrm{Al}-13.5 \mathrm{Si}-0.03 \mathrm{P}$ alloy. However, the phosphorus content in their study was significantly higher than the typical impurity levels in hypoeutectic $\mathrm{Al}-\mathrm{Si}$ alloys. ${ }^{[23]}$

The formation of an AlP particle consumes phosphorus from the surrounding liquid, and, consequently, the precipitation of new AlP particles in close vicinity of a pre-existing AlP is likely suppressed. Therefore, it is possible that a high amount of AlP particles form or pre-exist at different locations in the solidifying casting and later are carried by interdendritic liquid flow towards the casting surface, i.e., by the inverse segregation mechanism. ${ }^{[28]}$ Both oxides ${ }^{[15]}$ and $\mathrm{AlP}^{[11]}$ are expected to be rejected by the growing $\alpha$-Al crystals. Additionally, additional AlP can form ahead of the solid-liquid interface when the critical phosphorus content is reached. ${ }^{[11]}$ Consequently, pushing by the solidification front is likely to cause AlP particles and oxides to be enriched and become co-located in the remaining liquid. ${ }^{[11]}$

The movement of solute-enriched liquid through the mushy zone towards the casting surface, i.e., by the 
Table II. Average Silicon Concentration Measured in the Interior of the Slurry $\alpha$-Al Globules and the Corresponding Slurry Temperature Calculated in Thermocalc ${ }^{\mathrm{TM}}$

Thermocalc ${ }^{\mathrm{TM}}$ Calculation

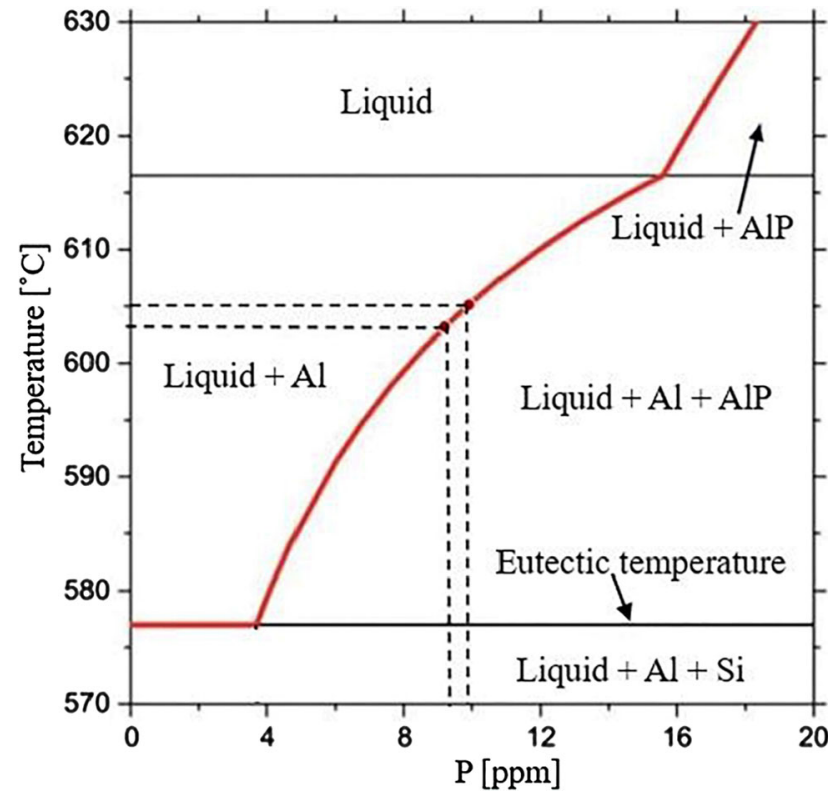

Fig. 4-Vertical section of the Al-7Si-P phase diagram adapted from Ref. [7]. The full red line indicates the stability limit of AlP. The black dashed lines denote the lower and higher slurry temperatures of the $\mathrm{SSM} \mathrm{Al}-7 \mathrm{Si}-\mathrm{M}$ castings determined using Thermocalc ${ }^{\mathrm{TM}}$. (Colour figure online).

inverse segregation mechanism, ${ }^{[28]}$ may carry the existing AlP on the path towards the casting surface. The transported AlP may become adsorbed or trapped and consequently accumulate on an oxide surface that can act as a barrier for the particles. Morales et al. ${ }^{[29]}$ reported a strong tendency for phosphorus to be adsorbed on the surface of $\gamma-\mathrm{Al}_{2} \mathrm{O}_{3}$, causing a reduction in total surface energy. Therefore, AlP may also tend to be adsorbed on the surface of oxides. The high AlP particle concentration in the liquid near the oxide surface can result in an increase in nucleation frequency of primary type silicon polyhedral crystals, as shown in Figures 2(a) and 3(a). Most of the AlP particles surrounding the oxides are not expected to become deactivated by $\mathrm{Al}_{2} \mathrm{Si}_{2} \mathrm{Sr}$ due to their narrow spacing.

Strontium $^{[23]}$ and phosphorus ${ }^{[7]}$ are rejected into the interdendritic liquid during the growth of $\alpha-\mathrm{Al}$. When the critical level of phosphorus and strontium are reached, $\mathrm{AlP}$ and $\mathrm{Al}_{2} \mathrm{Si}_{2} \mathrm{Sr}$ respectively, are formed. The formation sequence of $\mathrm{AlP}$ and $\mathrm{Al}_{2} \mathrm{Si}_{2} \mathrm{Sr}$ for a certain Al-Si alloy is influenced by the level of phosphorus and strontium in the liquid. ${ }^{[10]}$ Primary type silicon crystals can nucleate on AlP in hypoeutectic Al-Si alloys. ${ }^{[20]}$ The nucleation of the primary type silicon on AlP dispersed in the remained liquid can occur at higher temperatures compared to the $\mathrm{Al}_{2} \mathrm{Si}_{2} \mathrm{Sr}$ and Al-Si eutectic. These primary type crystals formed on AlP can also be transported towards the casting surface (by the inverse segregation mechanism) and become trapped on the oxide surface, as shown in Figure 3(a).

In this study, coarse polyhedral silicon crystals were observed in the vicinity of oxides located near the surface of strontium modified SSM Al-7Si-Mg castings. The phosphorus concentration at the location of the oxides was higher compared to the surroundings suggesting the possible presence of AlP particles that act as potent substracts for the nucleation of silicon. These AlP particles can pre-exist from the $\mathrm{Al}-7 \mathrm{Si}-\mathrm{Mg}$ ingots and remain active after melting. Additional AlP particles can also precipitate in the slurry during holding in the shot sleeve before injection into the die-cavity. Both AlP and oxides are likely pushed by the growing $\alpha$-Al crystals. The flow of solute-enriched liquid through the mushy zone towards the casting surface by the inverse segregation mechanism may supply extra AlP particles which can become adsorbed or trapped on oxide surfaces. The proximity of the AlP particles adsorbed by the oxide surface likely inhibits the deactivation by the $\mathrm{Al}_{2} \mathrm{Si}_{2} \mathrm{Sr}$ formation. Another possibility is that AlP particles nucleated on the outer wetted surface of oxide double film surrounding the macrosegregation regions, and subsequently, nucleate the primary type silicon crystals. Further studies are required to obtain clear evidences of the mechanisms responsible for the formation of primary type silicon crystals near oxides in semi-solid castings processing.

This work was funded by VINNOVA under the FatSS project (Dnr 2014-05096) and part of the LIGHTER programme, Knowledge Foundation (Dnr. 20100280) and Compcast Plus (Dnr. 20170066). The authors are also grateful for the support from Volvo Lastvagnar AB, COMPtech AB, Fueltech AB in this research.

The authors declare that they have no conflict of interest. 
Open access funding provided by Jönköping University.

\section{OPEN ACCESS}

This article is licensed under a Creative Commons Attribution 4.0 International License, which permits use, sharing, adaptation, distribution and reproduction in any medium or format, as long as you give appropriate credit to the original author(s) and the source, provide a link to the Creative Commons licence, and indicate if changes were made. The images or other third party material in this article are included in the article's Creative Commons licence, unless indicated otherwise in a credit line to the material. If material is not included in the article's Creative Commons licence and your intended use is not permitted by statutory regulation or exceeds the permitted use, you will need to obtain permission directly from the copyright holder. To view a copy of this licence, visit http://creat ivecommons.org/licenses/by/4.0/.

\section{REFERENCES}

1. K. Nogita, S.D. McDonald, and A.K. Dahle: Philos. Mag., 2004, vol. 84 , pp. 1683-96.

2. J. Li, F.S. Hage, X. Liu, Q. Ramasse, and P. Schumacher: Sci. Rep., 2016, pp. 1-8.

3. C.R. Ho and B. Cantor: J. Mater. Sci., 1995, vol. 30, pp. 1912-20.

4. K. Nogita, S.D. McDonald, K. Tsujimoto, K. Yasuda, and A.K. Dahle: J. Electron Microsc., 2004, vol. 53, pp. 361-69.

5. S.D. McDonald, K. Nogita, and A.K. Dahle: Acta Mater., 2004, vol. 52 , pp. $4273-80$.

6. US 6,336,955 B1: 2002, 1, vol. 1 .

7. S. Liang and R. Schmid-Fetzer: Acta Mater., 2014, vol. 72, pp. 41-56.
8. M. Riestra, E. Ghassemali, T. Bogdanoff, and S. Seifeddine: Mater. Sci. Eng. A, 2017, vol. 703, pp. 270-79.

9. M. Zamani, S. Seifeddine, and M. Aziziderouei: in Light Metals 2013, B.A. Sadler, ed., Springer, Cham, 2016, pp. 297-302.

10. J. Eiken, M. Apel, S.M. Liang, and R. Schmid-Fetzer: Acta Mater., 2015, vol. 98, pp. 152-63.

11. Y.H. Cho and A.K. Dahle: Metall. Mater. Trans. A, 2009, vol. 40, pp. 1011-12.

12. A.K. Dahle, K. Nogita, S.D. McDonald, C. Dinnis, and L. Lu: Mater. Sci. Eng. A, 2005, vols. 413-414, pp. 243-48.

13. X. Cao and J. Campbell: Met. Mater. Trans. A, 2003, vol. 34, pp. 1409-20.

14. J. Campbell: Materials, 2021, vol. 14, pp. 1-19.

15. J. Campbell: Metall. Mater. Trans. A, 2009, vol. 40A, pp. 1009-10.

16. RheoMetal, http://www.rheometal.com/componentb1.php, (accessed 26 August 2020).

17. O. Granath, M. Wessén, and H. Cao: Int. J. Cast. Met. Res., 2008, vol. 21 , pp. $349-56$.

18. S.G. Lee, G.R. Patel, and A.M. Gokhale: Scr. Mater., 2005, vol. 52, pp. 1063-68.

19. S.M. Liang and R. Schmid-Fetzer: in IOP Conference Series: Materials Science and Engineering, vol. 117, 2016.

20. T.H. Ludwig, P.L. Schaffer, and L. Arnberg: Metall. Mater. Trans. $A$, 2013, vol. 44A, pp. 5796-5805.

21. K. Nogita and A.K. Dahle: Mater. Trans., 2001, 42, vol. 42.

22. K. Mukai: Talanta, 1972, vol. 19, pp. 489-95.

23. Y.H. Cho, H.C. Lee, K.H. Oh, and A.K. Dahle: Metall. Mater. Trans. A, 2009, vol. 39A, pp. 2435-48.

24. H.I. Laukli, L. Arnberg, and O. Lohne: Int. J. Cast. Met. Res., 2005, vol. 18, pp. 65-72.

25. M. Payandeh, A.E.W. Jarfors, and M. Wessén: Metall. Mater. Trans. A, 2016, vol. 47A, pp. 1215-28.

26. H. Lescuyer, M. Allibert, and G. Laslaz: J. Alloys Compd., 1998, vol. 279 , pp. $237-44$.

27. X. Zhu, Y. Wu, C. Li, P. Li, H. Qiao, and X. Liu: CrystEngComm, 2014, vol. 16, pp. 5583-90.

28. C.M. Gourlay, H.I. Laukli, and A.K. Dahle: Metall. Mater. Trans. A, 2007, vol. 38A, pp. 1833-44.

29. A. Morales, M.M.R. de Agudelo, and F. Hernández: Appl. Catal., 1988, vol. 41, pp. 261-71.

Publisher's Note Springer Nature remains neutral with regard to jurisdictional claims in published maps and institutional affiliations. 